\title{
SYNTHESIS AND AChE INHIBITING ACTIVITY OF 2, 4 SUBSTITUTED 6-PHENYL PYRIMIDINES
}

\author{
${ }^{1}$ CRISTIAN PAZ, ${ }^{2}$ MARTIN G. PETER, ${ }^{2}$ BERND SCHMIDT, I JOSÉ BECERRA, ${ }^{3}$ MARGARITA GUTIÉRREZ, \\ ${ }^{3}$ LUIS ASTUDILLO, ${ }^{1}$ MARIO SILVA*
}

\author{
${ }^{1}$ Laboratorio de Química de Productos Naturales, Universidad de Concepción, Chile \\ ${ }^{2}$ Institute of Chemistry, University of Potsdam, Germany \\ ${ }^{3}$ Instituto de Química, Universidad de Talca, Chile \\ (Received: March 6, 012 - Accepted: June 29, 2012)
}

\begin{abstract}
Novel substituted pyrimidines were synthesized from methyl 2,4-dioxo-4-phenyl-butanoate (I-A) and urea, followed by Mitsunobu coupling of I-A with benzyl or allyl alcohol to give the corresponding 2-hydroxypyrimidine ethers in good yields. Saponification of I-A, followed by reaction with benzyl or allyl amines in the presence of TBTU yielded 2-hydroxy-6-phenyl-pyrimidine 4-carboxamides. AChE and BuChE assays revealed 2-hydroxy-6-phenyl-pyrimidine-4carboxyallyamide as the most active compound, $\mathrm{IC}_{50}=90 \mu \mathrm{M}$, with no inhibition of BuChE.
\end{abstract}

Keywords: Pyrimidines; inhibition AChE; mitsunobu; TBTU

\section{INTRODUCTION}

Alzheimer's disease (AD) is the most common age-related neurodegenerative disease, is a progressive neurodegenerative disorder that affects regions of the brain that control cognition, memory, language, speech and awareness to one's physical surroundings ${ }^{1}$. Those alterations are associated with regional deficits in the cholinergic system. The development of acetylcholinesterase (AChE) inhibitor drugs has followed the finding that cholinergic pathways in the cerebral cortex and basal forebrain are compromised in $\mathrm{AD}^{2}$ and the resultant cholinergic deficit contributes to the cognitive impairment of these patients ${ }^{3}$. Cholinesterase inhibitors (ChEIs) are considered to be valuable as a therapeutic target and they have become the main approach to symptomatic treatment; Donepezil, galantamine and rivastigmine are the first line pharmacotherapy for mild to moderate Alzheimer's disease $^{4}$. The drugs have slightly different pharmacological properties, but they all work by inhibiting the breakdown of acetylcholine increasing the availability of acetylcholine in central synapses ${ }^{4}$. Acetylcholinesterase and butyrylcholinesterase $(\mathrm{BuChE})$, the two forms of cholinesterase, co-exist ubiquitously throughout the body. They exhibit a high catalytic power and are very similar in structure and catalytic function. However, $\mathrm{BuChE}$ has a less defined role in biological processes, although it has been postulated that it acts as a detoxifying enzyme ${ }^{5}$.

Looking for new active compounds we have isolated several natural alkaloids from Aristotelia chilensis $^{6}$, which have displayed broad range of pharmacology activities. Recently investigations have shown that substituted pyrimidines are potent $\mathrm{ChE}$ inhibitors ${ }^{7}$ of Acetyl and Butylcholine. Therefore it seems interesting to synthesize 6-phenylpyrimidines as specific $\mathrm{ChE}$, substituted at position 2 and 4 and evaluated their enzymatic activity.

\section{EXPERIMENTAL}

Melting points were determined on a Melting Point SMP10 (Stuart) and are uncorrected. The ${ }^{1} \mathrm{H}$ NMR spectra were determined using a Bruker ARX 300 instrument, operating at $300.1 \mathrm{MHz}\left({ }^{1} \mathrm{H}\right)$ and $75.5 \mathrm{MHz}\left({ }^{13} \mathrm{C}\right)$ or Bruker ARX 500 operating at $500 \mathrm{MHz}\left({ }^{1} \mathrm{H}\right)$ and $125 \mathrm{MHz}\left({ }^{13} \mathrm{C}\right)$. High-Resolution ESI mass spectra (HR-MS) were measured on a Q-TOF mass spectrometer Micromass (Manchester). EI low-resolution MS spectra were measured on Trace DSQII GC/MS-system Axel Semrau GmbH \& Co). Column chromatography was performed using Merck silica gel $60(0.063-0.200 \mathrm{~mm})$. TLC was carried out on a Merck silica gel 60 PF254. Solvents used in this study were distilled prior to use and dried over appropriate drying agents.

\section{Enzyme assays}

The in vitro measurement of $\mathrm{AChE}$ and $\mathrm{BuChE}$ inhibition were carried out using a colorimetric method ${ }^{8}$ adapted to 96 -well microtiter plates ${ }^{9}$. The AChE was obtained from Electrophorus electricus (C3389-500UN), type VI-S, Sigma Chemical Co., St. Louis, MO), and BuChE from equine serum (C1057$1 \mathrm{KU}$, Sigma Chemical Co., St. Louis, MO). Fifty $\mu \mathrm{L}$ of test sample dissolved in $100 \mathrm{mM}$ phosphate buffer $\mathrm{pH} 7.6$, and $50 \mu \mathrm{L}$, of $\mathrm{AChE}$ or BuChE solution (final concentration of $0.03 \mathrm{U} / \mathrm{mL}$ and $0.01 \mathrm{U} / \mathrm{mL}$, respectively) were added to each well, and the plates were pre-incubated for $30 \mathrm{~min}$ at room temperature. After the pre-incubation period, acetylthiocholine iodide (or butyrylthiocholine iodide) was added to a final concentration of $200 \mu \mathrm{M}$. 5,5'-Dithio-bis(2nitrobenzoic acid) (DTNB) was used for the measurement of cholinesterase activity. The hydrolysis of $\mathrm{ACh}$ or $\mathrm{BCh}$ was monitored by following the formation of the yellow 5-thio-2-nitrobenzoate anion. The absorbance was read in a Thermo Multiskan Ex Instrument microplate reader at $405 \mathrm{~nm}$ after 3 min. The enzyme activity was calculated as a percentage compared to a control using only the buffer and enzyme solution. The compounds were assessed in the dilution interval of $500-15.63 \mu \mathrm{g} / \mathrm{mL}$, and the alkaloid galanthamine was used as the reference compound. The ChEs inhibitory activity of each compounds was expressed in terms of the $\mathrm{IC}_{50}$ value $(\mu \mathrm{g} / \mathrm{mL}$ and $\mu \mathrm{M}$ required to inhibit the hydrolysis of the substrate by $50 \%$ ), as calculated from the doseresponse curve.

\section{RESULTS AND DISCUSSION}

2, 4-Dioxobutanoates are interesting starting materials for the synthesis of ligands and organometallic complexes of anti-HIV-1 integrase ${ }^{10}$. Amides and hydrazides of 2, 4-dioxobutanoic acid possess antimicrobial and analgesic activity $^{11}$. The $\beta$ diketone I-A has been synthesized in $84 \%$ yield from the acetophenone and dimethyloxalate in dimethoxyethane, using $\mathrm{NaH}$ as base, scheme 1. Compound I-A shows an interchangeable proton at $15.83 \mathrm{ppm}$ and just one ketone carbon at $190.81 \mathrm{ppm}$ suggesting that I-A occurs only as the $\beta$-hydroxyketone.

Hydrolysis of I-A in aqueous $\mathrm{NaOH}$ for 10-15 min gave the corresponding acid II-B in $80 \%$ yield. II-B is known to possess promising activity against HIV-1 integrase ${ }^{7}$ and slow-binding inhibition of KDPG aldolase ${ }^{12}$ which is a target for new bacteriostatic or bactericidal drugs. Other reaction conditions, such as $\mathrm{NaOH}$ in $\mathrm{MeOH}$, afforded II-B in a yield of ca. $50 \%$, together with unreacted starting material.

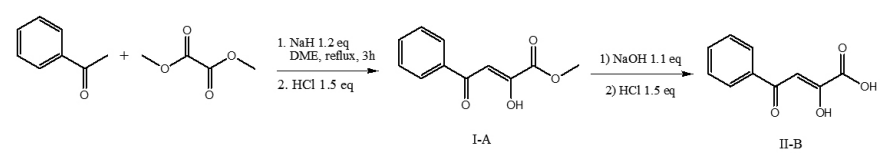

Scheme 1

Pyrimidine I-A1 was synthesized from $\beta$-hydroxy ketone I-A in $78 \%$ yield, using an excess of urea in $\mathrm{MeOH}$ under reflux in the presence of catalytic amounts of $\mathrm{H}_{2} \mathrm{SO}_{4}$. Ethers I-A2 and I-A3 were obtained from I-A1 under Mitsunobu conditions, using diisopropylazodicarboxylate (DIAD) and Triphenylphosphine in dimethylformamide. Column chromatography afforded the products in ca. $87 \%$ yield, scheme 2 . 


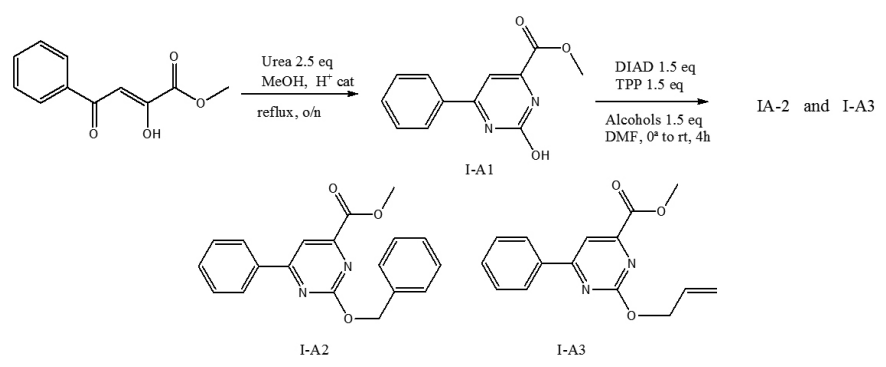

Scheme 2

Reaction of 4-phenyl-2,4-dioxobutanoic acid (II-B) with an excess of urea and catalytic amounts of $\mathrm{H}_{2} \mathrm{SO}_{4}$ in refluxing toluene gave 2-hydroxy6-phenylpyrimidine-4-carboxylic acid (II-BI) in yields of ca. 55\%. II-BI precipitated after the reaction as a white solid, soluble in dimethylsulfoxide or dimethylformamide. Amide coupling of II-B1 with benzyl or allyl amines with O-(Benzotriazol-1-yl)-N,N,N',N'-tetramethyluroniumtetrafluoroborate (TBTU) in DMF gave compounds II-B2, II-B3, and II-B4, respectively, in ca. $40 \%$ yield, scheme 3 . Attempts to prepare secondary amides with diethyl- or dibenzylamine were unsuccessful, as only traces of product were detected


Scheme 3

Compounds I-A2; I-A3; II-B2; II-B3; II-B4, as well as pyrimidines I-A1 and II-B1 were evaluated as inhibitors of AChE (Table 1). All amides showed higher activity than pyrimidine carboxylic acid, II-B1. The most active compound was the allyl amide II-B3 with an $\mathrm{IC}_{50}$ of $90.1 \mu \mathrm{M}$. All compounds were also tested with $\mathrm{BuChE}$, but did not show significant inhibition $\left(\mathrm{IC}_{50}>\right.$ $1000 \mu \mathrm{M})$.

Table 1. Activity of 6-phenyl pyrimidine 2,4 substituted toward the enzyme AChE.

\begin{tabular}{|cl|cc|}
\hline \multirow{2}{*}{ Entry } & \multicolumn{2}{c|}{ Compound } & \multicolumn{2}{c|}{$\mathrm{AChE} \mathrm{IC} \mathrm{I}_{50}$} \\
& $\mathrm{mg} / \mathrm{mL}$ & $\mu \mathrm{M}$ \\
\hline 1 & $\mathrm{I}-\mathrm{A} 1$ & 0.024 & 104.3 \\
2 & $\mathrm{I}-\mathrm{A} 2$ & 0.089 & 278.0 \\
3 & $\mathrm{I}-\mathrm{A} 3$ & 0.032 & 118.0 \\
4 & $\mathrm{II}-\mathrm{B} 1$ & 0.081 & 375.0 \\
5 & $\mathrm{II}-\mathrm{B} 2$ & 0.059 & 184.0 \\
6 & $\mathrm{II}-\mathrm{B} 3$ & 0.023 & 90.1 \\
7 & $\mathrm{II}-\mathrm{B} 4$ & 0.063 & 185.8 \\
$*$ Galantamine & & $1.1 \times 10^{-3}$ & 3.0 \\
& & & \\
\hline
\end{tabular}

* Internal control, $\mathrm{n}=3$.

(Z)-Methyl 2-hydroxy-4-oxo-4-phenylbut-2-enoate (I-A): A mixture of acetophenone $(5 \mathrm{~g}, 41.7 \mathrm{mmol})$ and dimethyloxalate $(5.9 \mathrm{~g}, 50 \mathrm{mmol})$ were stirred in $150 \mathrm{~mL}$ of anhydrous dimethoxyethane, then sodium hydride $(1.2 \mathrm{~g}$, $50 \mathrm{mmol}$ ) was added. The mixture was stirred under reflux for $4 \mathrm{~h}$. The reaction was cooled and quenched with water $100 \mathrm{~mL}$ and $\mathrm{HCl}$ until $\mathrm{pH} 2$. The mixture was extracted 3 times with EtOAc, and the organic layer was evaporated in vacuo. The compound precipitated as a white solid (7.2g, 84\%). ${ }^{1} \mathrm{H}-\mathrm{NMR}$ $\left(\mathrm{CDCl}_{3}, 300 \mathrm{MHz}\right) \mathrm{ppm}: 3.94(3 \mathrm{H}, \mathrm{s}) ; 7.10(1 \mathrm{H}, \mathrm{s}) ; 7.50(2 \mathrm{H}, \mathrm{m}) ; 7.61(1 \mathrm{H}$, $\mathrm{m}) ; 8.00(2 \mathrm{H}, \mathrm{m}), 15.83\left(1 \mathrm{H}, \mathrm{s}\right.$, interchangeable). ${ }^{13} \mathrm{C}-\mathrm{NMR}\left(\mathrm{CDCl}_{3}, 75 \mathrm{MHz}\right)$ ppm: 55.41; 99.45; 127.55; 129.16; 130.19; 135.16; 162.61; 169.09; 190.81 . EI-MS: 206

Methyl 2-hydroxy-6-phenylpyrimidine-4-carboxylate (I-A1): A mixture of compound I-A $(3.0 \mathrm{~g}, 14.6 \mathrm{mmol})$ and urea $(2.8 \mathrm{~g}, 47 \mathrm{mmol})$ were dissolved in $100 \mathrm{~mL}$ of methanol and ca. $100 \mu \mathrm{L}$ of conc. sulfuric acid was added. The solution was stirred overnight. The product precipitated as a white solid $(2.8 \mathrm{~g}, 78 \%) \mathrm{mp}=195-196^{\circ} \mathrm{C} .{ }^{1} \mathrm{H}-\mathrm{NMR}$ (DMSO-d6, $500 \mathrm{MHz}$ ) ppm: 3.91 $(3 \mathrm{H}, \mathrm{s}) ; 7.59(3 \mathrm{H}, \mathrm{m}) ; 7.72(1 \mathrm{H}, \mathrm{s}) ; 8.13(2 \mathrm{H}, \mathrm{d}, \mathrm{J}=7.2 \mathrm{~Hz}) ; 12.47(1 \mathrm{H}, \mathrm{s}, \mathrm{br})$. ${ }^{13} \mathrm{C}-\mathrm{NMR}$ (DMSO-d6, $125 \mathrm{MHz}$ ) ppm: 53.50; 105.98; 127.92; 129.51; 132.40; $135.23 ; 155.43 ; 162.54 ; 163.78 ; 168.22$.

Methyl 2-(benzyloxy)-6-phenylpyrimidine-4-carboxylate (I-A2): DIAD $(1.49 \mathrm{~g}, 7.4 \mathrm{mmol})$ in $10 \mathrm{~mL}$ of dry THF was cooled in an ice bath, then triphenylphospine $(1.93 \mathrm{~g}, 7.4 \mathrm{mmol})$ dissolved in $10 \mathrm{~mL}$ of THF was added, the mixture was stirred for $15 \mathrm{~min}$, during which a white solid was formed. A mixture of I-A1 $(1.13 \mathrm{~g}, 4.9 \mathrm{mmol})$ and benzyl alcohol $(0.78 \mathrm{~g}, 7.2 \mathrm{mmol})$ dissolved in $15 \mathrm{~mL}$ of dry dimethylformamide was added to the suspension. The reaction was stirred for $5 \mathrm{~h}$ from $0{ }^{\circ} \mathrm{C}$ to room temperature. The solvents were removed in vacuo and the crude product was purified by silica gel column with hexane/EtOAc $30 \%$. White solid $(1.35 \mathrm{~g}, 86 \%) \mathrm{mp}=98^{\circ} \mathrm{C}$. ${ }^{1} \mathrm{H}-\mathrm{NMR}$ $\left(\mathrm{CDCl}_{3}, 300 \mathrm{MHz}\right) \mathrm{ppm}: 4.03(3 \mathrm{H}, \mathrm{s}) ; 5.60(2 \mathrm{H}, \mathrm{s}) ; 7.27-7.42(3 \mathrm{H}, \mathrm{m}) ; 7.46-$ $7.62(5 \mathrm{H}, \mathrm{m}) ; 8.07(1 \mathrm{H}, \mathrm{s}) ; 8.16(2 \mathrm{H}, \mathrm{dd}, \mathrm{J}=2.1,7.6 \mathrm{~Hz}) .{ }^{13} \mathrm{C}-\mathrm{NMR}\left(\mathrm{CDCl}_{3}\right.$, $75 \mathrm{MHz}$ ) ppm: $53.30 ; 69.80 ; 110.59 ; 127.63 ; 128.22 ; 129.12 ; 131.87 ; 135.98$; $136.45 ; 158.01 ; 164.96 ; 165.87 ; 168.78$. ESI-MS: M+1: 321.1137

Methyl 2-(allyloxy)-6-phenylpyrimidine-4-carboxylate (I-A3): The compound was prepared following the same procedure as described for I-A2, using allyl alcohol $(0.427 \mathrm{~g}, 7.3 \mathrm{mmol})$. The crude product was purified by CC with hexane-ethyl acetate $20 \%$, giving a white solid $(1.15 \mathrm{~g}, 87 \%) \mathrm{mp}=102-$ $103^{\circ} \mathrm{C} .{ }^{1} \mathrm{H}-\mathrm{NMR}(\mathrm{MeOD}, 300 \mathrm{MHz}) \mathrm{ppm}: 4.00(3 \mathrm{H}, \mathrm{s}) ; 4.91(2 \mathrm{H}, \mathrm{s}) ; 5.25(2 \mathrm{H}$, $\mathrm{m}) ; 6.00(1 \mathrm{H}, \mathrm{m}) ; 7.44(1 \mathrm{H}, \mathrm{s}) ; 7.57(3 \mathrm{H}, \mathrm{m}) ; 8.15(2 \mathrm{H}, \mathrm{m}) .{ }^{13} \mathrm{C}-\mathrm{NMR}(\mathrm{MeOD}$, $75 \mathrm{MHz}$ ) ppm: 43.14; 52.92; 103.29; 117.69; 127.74; 128.69; 131.95; 132.44; $135.13 ; 148.32 ; 157.10 ; 161.52 ; 171.68$. ESI-MS: M+1: 271.1389 .

(Z)-2-Hydroxy-4-oxo-4-phenylbut-2-enoic acid (II-B): Hydrolysis of I-A $(5.5 \mathrm{~g}, 26.7 \mathrm{mmol})$ was carried out with $\mathrm{NaOH}(1.1 \mathrm{~g}, 26.7 \mathrm{mmol})$ in $20 \mathrm{~mL}$ of water and stirring at $50^{\circ} \mathrm{C}$ for $15 \mathrm{~min}$. The reaction was filtered and the rection mixture was extracted three times with $10 \mathrm{~mL}$ of ethyl acetate. The water layer was acidified with $\mathrm{HCl}$ until $\mathrm{pH} 2$. The product precipitated as a white solid, it was filtered off and dried $(4.1 \mathrm{~g}, 80 \%), \mathrm{mp}=160^{\circ} \mathrm{C}$. ${ }^{1} \mathrm{H}-\mathrm{NMR}\left(\mathrm{CDCl}_{3}, 300\right.$ MHz) ppm: $6.75(1 \mathrm{H}, \mathrm{br}) ; 7.52(2 \mathrm{H}, \mathrm{m}) ; 7.53(1 \mathrm{H}, \mathrm{d}, \mathrm{J}=4.2 \mathrm{~Hz}) ; 7.87(2 \mathrm{H}, \mathrm{d}$, $\mathrm{J}=4.5 \mathrm{~Hz}) .{ }^{13} \mathrm{C}-\mathrm{NMR}\left(\mathrm{CDCl}_{3}, 75 \mathrm{MHz}\right) \mathrm{ppm}: 98.04 ; 127.48 ; 128.00 ; 128.42$; 128.90; 133.05; 135.44; 163.81. EI-MS: 192

2-Hydroxy-6-phenylpyrimidine-4-carboxylic acid (II-B1): A mixture of II-B $(1.0 \mathrm{~g}, 5.2 \mathrm{mmol})$, urea $(0.98 \mathrm{~g}, 16.3 \mathrm{mmol})$ and ca. $100 \mu \mathrm{L}$ of conc. sulfuric acid were dissolved in $100 \mathrm{~mL}$ of toluene and stirred overnight, during which a brown solid precipitated, which was filtered off and washed with cold methanol. White solid $(0.7 \mathrm{~g}, 62.2 \%)$, decomposes at ca. $215^{\circ} \mathrm{C},{ }^{1} \mathrm{H}-\mathrm{NMR}$ (DMSO d6, $300 \mathrm{MHz})$ ppm: 7.25-7.60 (4H, m, overlap); $8.13(2 \mathrm{H}, \mathrm{dd}, \mathrm{J}=2$; $6 \mathrm{Mz}$ ). ${ }^{13} \mathrm{C}-\mathrm{NMR}$ (DMSO d6, $75 \mathrm{MHz}$ ) ppm: 103.8; 128.40; 129.83; 132.75; $136.14 ; 154.67 ; 160.61 ; 164.00 ; 169.86$. ESI-MS: M+1: 217.0711

2-Hydroxy-N-(3-metoxyphenyl)-6-phenylpyrimidine-4-carboxamide (II-B2): A mixture of 2-hydroxy-6-phenylpyrimidine-4-carcarboxylic acid (150mg, $0.69 \mathrm{mmol})$ and $\mathrm{N}, \mathrm{N}$-Diisopropylethylamine $(180 \mathrm{mg}, 1.4 \mathrm{mmol})$ were dissolved in $10 \mathrm{~mL}$ of dry DMF, then O-(Benzotriazol-1-yl)-N,N,N',N'-tetram ethyluroniumtetrafluoroborate (TBTU) $(268 \mathrm{mg}, 0.83 \mathrm{mmol})$ was added. The mixture was stirred for $30 \mathrm{~min}$ at $0^{\circ} \mathrm{C}$, and 3 -methoxyaniline $(94 \mathrm{mg}, 0.76 \mathrm{mmol})$ was added. The reaction was stirred for $3 \mathrm{~h}$, then the reaction was quenched with $\mathrm{H}_{2} \mathrm{O}$, and the DMF was removed in vacuo $\left(5 \mathrm{mmbar}\right.$ and $\left.60^{\circ} \mathrm{C}\right)$, the crude was purified by CC with hexane-ethyl acetate $50 \%$. Yellow solid $(100 \mathrm{mg}$, 45\%), decomposes at ca. $205^{\circ} \mathrm{C} .{ }^{1} \mathrm{H}-\mathrm{NMR}$ (DMSO d6, $300 \mathrm{MHz}$ ) ppm: 3.77 $(3 \mathrm{H}, \mathrm{s}) ; 6.76(1 \mathrm{H}, \mathrm{dd}, \mathrm{J}=3.0 ; 9.0 \mathrm{~Hz}) ; 7.31(1 \mathrm{H}, \mathrm{dd}, \mathrm{J}=9 ; 15 \mathrm{~Hz}) ; 7.4-7.7$ $\left(6 \mathrm{H}, \mathrm{m}\right.$, overlap); $7.80(2 \mathrm{H}, \mathrm{d}, \mathrm{J}=9 \mathrm{~Hz}) ; 10.51(1 \mathrm{H}, \mathrm{s}) .{ }^{13} \mathrm{C}-\mathrm{NMR}$ (DMSO d6, $75 \mathrm{MHz}$ ) ppm: $55.95 ; 107.03 ; 110.45 ; 110.95 ; 113.48 ; 120.86 ; 126.23 ; 128.19$; $128.36 ; 129.93 ; 130.42 ; 132.75 ; 134.87139 .87 ; 143.75 ; 160.30$. ESI-MS, M+1: 322.1339

N-Allyl-2-hydroxy-6-phenylpyrimidine-4-carboxamide (II-B3): The compound was prepared following the same procedure as described for II-B2, using allylamine ( $87 \mathrm{mg}, 2.0 \mathrm{mmol})$. White solid $(140 \mathrm{mg}, 40 \%)$, decomposes at ca. $150^{\circ} \mathrm{C}$. ${ }^{1} \mathrm{H}-\mathrm{NMR}(\mathrm{MeOD}, 300 \mathrm{MHz})$ ppm: $4.04(2 \mathrm{H}, \mathrm{m}) ; 5.20(2 \mathrm{H}, \mathrm{m})$; $5.94(1 \mathrm{H}, \mathrm{m}) ; 7.48-7.65(4 \mathrm{H}, \mathrm{m}) ; 7.96(2 \mathrm{H}, \mathrm{d}, \mathrm{J}=3,6 \mathrm{~Hz}) .{ }^{13} \mathrm{C}-\mathrm{NMR}(\mathrm{MeOD}$, $75 \mathrm{MHz}$ ) ppm: $43.14 ; 111.57 ; 116.90 ; 118.82 ; 127.28 ; 128.42 ; 128.80 ; 130.54$; $133.55 ; 134.97 ; 164.39 ; 173.15$. ESI-MS: M+1: 256.1131

N-(2-Chlorobenzyl)-2-hydroxy-6-phenylpyrimidine-4-carboxamide (II-B4): The compound was prepared following the same procedure as described for IIB2, using 2-chlorobenzyl amine (216 mg, 1.53mmol). White 
solid (200mg, 43\%), decomposes at ca. $205{ }^{\circ} \mathrm{C} .{ }^{1} \mathrm{H}-\mathrm{NMR}$ (DMSO d6, 300 MHz) ppm: $4.58(2 \mathrm{H}, \mathrm{d}, \mathrm{J}=3 \mathrm{~Hz}) ; 7.29-7.35(2 \mathrm{H}, \mathrm{m}) ; 7.42(1 \mathrm{H}, \mathrm{t}, \mathrm{J}=3 \mathrm{~Hz})$; $7.53-7.60(4 \mathrm{H}, \mathrm{m}) ; 7.73(1 \mathrm{H}, \mathrm{d}, \mathrm{J}=6 \mathrm{~Hz}) ; 8.00(1 \mathrm{H}, \mathrm{d}, \mathrm{J}=3 \mathrm{~Hz}) ; 8.07(1 \mathrm{H}, \mathrm{d}$ $\mathrm{J}=3 \mathrm{~Hz}$ ); $9.38(1 \mathrm{H}, \mathrm{s}) .{ }^{13} \mathrm{C}-\mathrm{NMR}$ (DMSO d6, $\left.75 \mathrm{MHz}\right) \mathrm{ppm}$ : 41.01; 110.08; $119.60 ; 125.00 ; 127.67 ; 127.79 ; 127.95 ; 128.29 ; 129.08 ; 129.18 ; 129.55$; $129.61 ; 133.00 ; 136.19 ; 143.30 ; 163.37$. ESI-MS: M+1: 340.1096

\section{CONCLUSIONS}

The investigation described in this communication reports the synthesis of substituted pyrimidines in few steps with goods yields and simplicity of operations. Separately we modified the pyrimidine substituent at position 2 through Mitsunobu reaction and the carboxy group at position 4 by amidation. All compounds were evaluated as AChE inhibitors showing that position 4 is the most important for enzyme-inhibition. N-Allyl-2-hydroxy-6phenylpyrimidine-4-carboxamide (II-B3) is the most active compound against AChE with $\mathrm{IC}_{50} 90.1 \mu \mathrm{M}$. It is highly selective for $\mathrm{AChE}$, not showing activity against BuChE.

\section{REFERENCES}

1. M. Holden, C. Kelly, Adv. Psychiatry Treat. 8, 89, (2002)

2. R. Katzman, T. Saitoh, FASEB J. 5, 278, (1991)

3. A. Terry and J. Buccafusco. JPET. 306, 821, (2003)

4. J. Birks. Cochrane Database Syst Rev. 25, 1, (2006)

5. D. Gorelick. Drug and alcohol dependence. 48, 159, (1997)

6. M. Silva, M. Bittner, C. Céspedes, J. Jakupovic. Bol. Soc. Chil. Quím. 42, 37, (1997)

7. T. Mohamed, J. Yeung, P. Rao, Bioorg Med Chem Lett. 21, 5881, (2011)

8. G.L. Ellman, K.D. Courtney, V.Jr. Andres, R.M. Featherstone, Biochem Pharmacol. 7, 88, (1961)

9. M. Gutierrez, C. Theoduloz, J. Rodriguez, M. Lolas, G. SchmedaHirschmann, J Agric Food Chemistry. 53, 7701, (2005)

10. M. Sechi, F. Carta, L. Sannia, R. Dallocchio, A. Dessi, R. Al-Safi, N. Neamati. Antivir Res. 81, 267, (2009)

11. E. Koz'minykh, A. belyaev, E. Berezina, V. Koz'minykh, R. Makhmudov, T. Odegova, Pharmaceut Chem J. 36, 643, (2002)

12. R. Braga, L. Hecquet, C. Blonski, Bioorg Med Chem. 12, 2965, (2004)

\section{ACKNOWLEDGEMENTS}

Authors like to thank the financial support from Universidad de Concepción and CONICYT for its Doctoral Scholarship Program. 